\title{
Analysis of the Mortgage Market in the Czech Republic
}

\author{
Martina HEDVIČÁKOVÁ ${ }^{1}$ and Alena POZDÍLKOVÁ ${ }^{2}$ \\ 1 University of Hradec Králové, Hradec Králové, Czech Republic; martina.hedvicakova@uhk.cz \\ 2 University of Pardubice, Pardubice, Czech Republic; alena.pozdilkova@upce.cz \\ * Corresponding author: martina.hedvicakova@uhk.cz
}

\begin{abstract}
During the beginning of 2020, the coronavirus pandemic spread worldwide. Governments have responded with tough restrictive measures. The Czech National Bank decided to support the economy and reduced the $2 \mathrm{~W}$ repo rate twice during March 2020 and for the third time in May 2020 to the current $0.25 \%$. In addition to low interest rates from the $\mathrm{CNB}$, there is very high competition in the mortgage market, which reduces the average interest rate on mortgage loans. Mortgage loans are thus more affordable. The aim of the article is to analyze the current situation on the mortgage market and predict their further development. Using correlation analysis will be shown, that trends of interest rate and number of mortgage loans and their volume are not similar. This will be illustrated by graph, which will show decreasing trend of interest rate and increasing rate of number and volume of mortgages. Using significance test of correlation co-efficient will be verified, that even the trends in absolute values are not similar.
\end{abstract}

Keywords: mortgage market; loan; interest rate; correlation analysis

JEL Classification: E43; G21

\section{Introduction}

A coronavirus pandemic has hit the world. In addition to the health of the population, this pandemic also affected the economies of the affected countries. The individual countries have taken restrictive measures to spread the virus, but these measures have had a severe impact on state budget expenditures. Governments are trying to stimulate the economy. Within the monetary economy, central banks are trying to support the economy with declining interest rates. Falling interest rates should stimulate the economy and make loans cheaper. This article focuses on the analysis of the mortgage market, which will also be affected by the crisis. Banks have learned from the previous financial and subsequent economic crisis and are working to eliminate risks. One way to minimize risks is to set a minimum amount of LTV, which the CNB regulates the mortgage market. Kinghan et al. (2019) find that LTVs fell by approximately 1.4 percentage points after the measures, with larger reductions recorded for high income borrowers.

Tse (1997) shows that under conditions of uncertainty when default risk is present, and if absolute risk aversion is increasing in wealth, a rise in wealth of the bank will lower the amount of asset to be allocated in risky loans even if credit can be properly priced. Chambers at al. (2009) find that the loan structure is a quantitatively significant factor in a household's 
housing finance decision. The model suggests that the mortgage structure preferred by a household is dependent on age and income and that loan products with low initial payments offer an alternative to mortgages with no down payment. These effects are more important when inflation is low. The presence of inflation reduces the real value of the mortgage payment and the outstanding loan over time reducing mobility.

Kokas et al. (2020) find that the higher their market power the lower is the growth rate of lending relative to de-posits. As a result, in periods of falling deposits higher market power for the average bank is associated with a greater fall in lending, consistent with amplification of adverse effects during relatively bad times. Kim (2015) analyze how mortgage loan modification policies, after a sudden drop in house prices, affect household choices in the mortgage and unsecured loan markets.

Mortgage loans can also be used to finance business activities or as collateral for households. A standard New Keynesian model is extended to include a rich financial system in which financially constrained banks lend to firms and homeowners via default long-term loans. The model generates two endogenous components of interest rate spreads on mortgages and corporate loans: i) a default premium and ii) a liquidity premium (Ferrante, 2019).

\section{Methodology and the Aim of the Paper}

Interest rate data ( $2 \mathrm{~W}$ repo rate) are from the Czech national bank. Data on interest rates on mortgage loans are from the Hypoindex. In the article they are presented as average interest rates in percentage for mortgage loans.

Mortgage loans have been a type of consumer loan since 1 December 2016. According to Act No. 257/2016 Coll., There is a new "consumer loan for housing", which significantly improves the position of consumers and regulates the business environment in this area. In this article, these loans will be referred to as mortgage loans or mortgages.

The aim of correlation analysis is to determine the strength of linear dependence between quantities. Then a zero correlation coefficient means that the quantities are independent. If the assumption of two-dimensional normality is not satisfied, the zero value of the correlation coefficient cannot be inferred more than that the quantities are uncorrelated. The closer the relationship between the two variables, the closer the absolute value of the correlation coefficient is to one. Negative correlation coefficients express indirect correlation (with increasing values of one variable the values of the other variable decrease). (Hedvicakova \& Pozdílková, 2018; Pozdílková \& Hedvičáková, 2017; Svobodova \& Hedvicakova, 2018)

Significance of correlation coefficient can be verified using significance test of the correlation coefficient. The test statistic is $T=r \sqrt{\frac{n-2}{1-r^{2}}}$, if $|T| \geq t_{n-2,0.975}$, time series are similar in character over a given time period (Draessler et al., 2011; Hedvicakova et al., 2020; Hedvičáková \& Pozdílková, 2018; Král, 2017).

The aim of this contribution is to analyze the current situation on the mortgage market and predict its further development with regard to the current economic situation in connection with the coronavirus pandemic. Based on the development of the $2 \mathrm{~W}$ interest rate, 
which the Czech National Bank is trying to revive the economy, the effects on mortgage loans will be analyzed and the development of the average interest rate on these loans will be predicted. The authors will also be based on the past crisis, when the Czech National Bank tried to stimulate the economy through a fall in interest rates.

Using correlation analysis will be shown trends of interest rate, number of mortgage loans and their volume. This analysis will be done for the period January 2019 to March 2020.

\section{Current Situation in the Mortgage Market}

The current average interest rate according to the Hypoindex for March 2020 is $2.44 \%$ for mortgage loans. Since January 2020, the average interest rate has been rising very slowly. The coronavirus pandemic has not yet reached the mortgage market. The volumes of provided mortgages increased again after a weak beginning of 2020 and also almost attacked the volumes from the strong year 2018. On the contrary, the average amount of provided mortgage loan stopped after seven months and its value decreased slightly to the current 2,546,560 CZK.

Mortgage volumes rose again in December 2020. In December, banks arranged mortgage loans worth more than 29.5 billion crowns. The average mortgage amount approached the limit of three million Czech crowns. According to the Fincentrum Hypoindex indicator, the average mortgage interest rate fell again to $1.96 \%$. This average interest rate on mortgage loans has been falling for nine months in a row. However, its decline is slowing down. While in May and June 2020 the average rate fell by another nine basis points, in December it was only two basis points (Hypoindex.cz, 2021b).

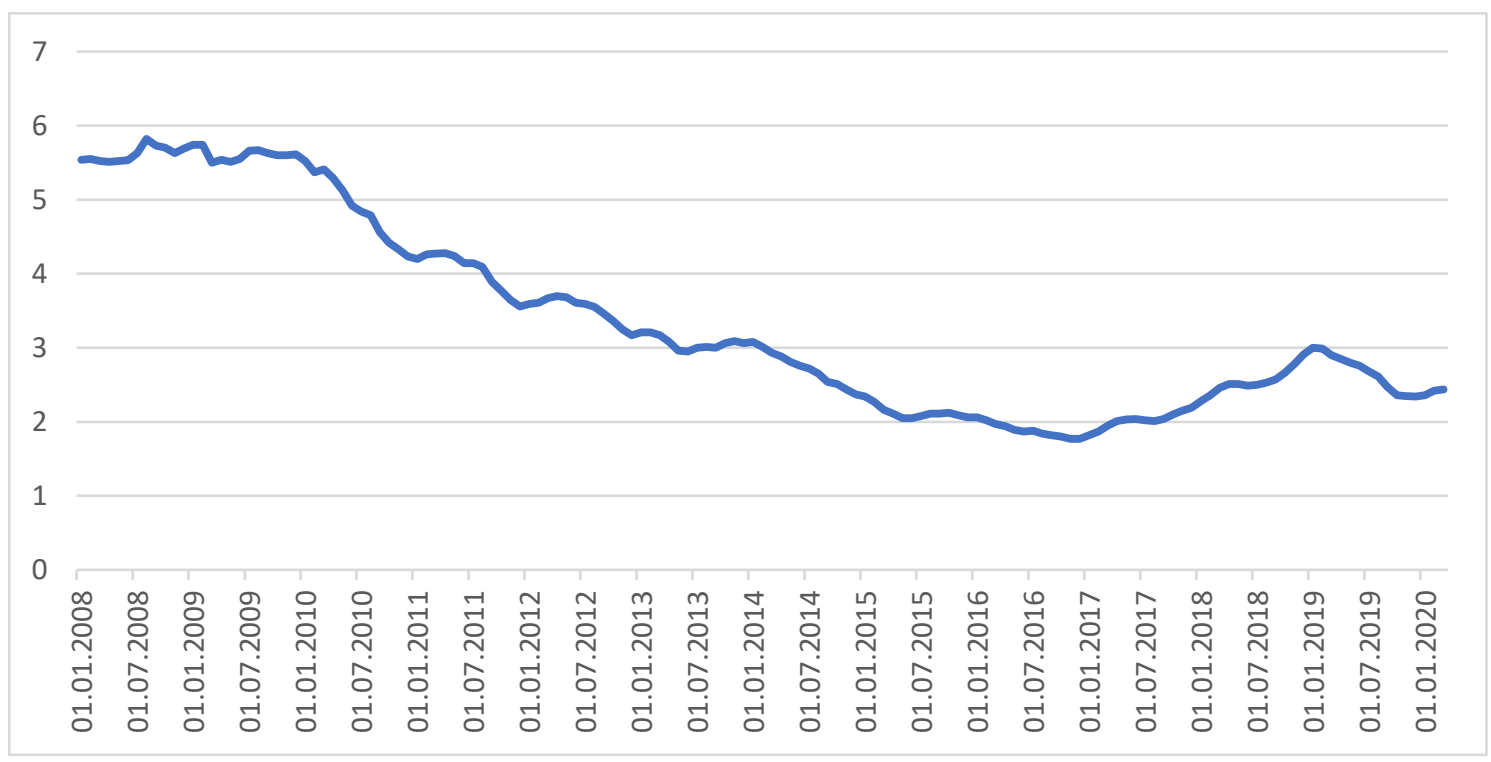

Figure 1. Interest rate in \%, source own processing using (Hypoindex.cz, 2021a)

The growing level of the average mortgage shows that the growth of real estate prices has not slowed much yet, despite the coronavirus crisis. Growth in property prices could slow down and stabilize in 2021 (Hypoindex.cz, 2021b). 
On February 7, 2020, the Czech National Bank (CNB) first increased the $2 \mathrm{~W}$ repo rate by $0.25 \%$ to $2.25 \%$. In the following month of March, due to the coronavirus pandemic, the CNB reduced the $2 \mathrm{~W}$ repo rate on March 17, 2020 to $1.75 \%$ and twenty days later to another $0.75 \%$ to $1 \%$. Due to the measures of the Czech government, the CNB responded on 11 May 2020 by further reducing the interest rate to the current $0.25 \%$.

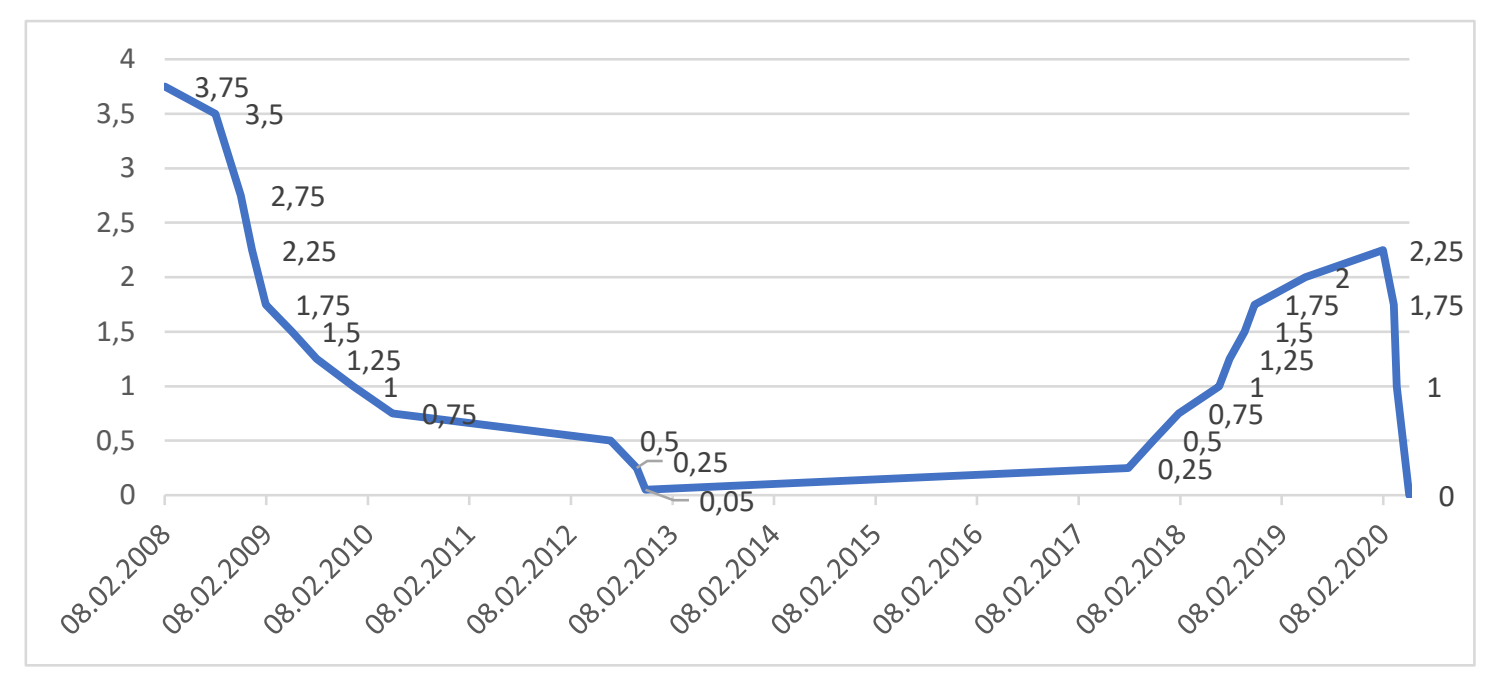

Figure 2. 2W Repo rate in \%, source own processing using (Česká národní banka, 2021)

Banks respond to the current market situation, where the economy is going into recession due to coronavirus, mainly by lowering LTV limits and lending less money to clients in relation to the mortgage value of real estate. The central bank relaxed credit limits for new mortgages. With effect from 1 April 2020, the Czech National Bank increased the LTV limit from 80 to 90 percent, with the exception of investment mortgages, the DSTI limit (the ratio of total debt to the net monthly income of the loan applicant) increased from 45 to 50 percent and the DTI limit (ratio of the amount of debt to the net income of the loan applicant) has been canceled. But banks prefer security and try to minimize risks (Hypoindex.cz, 2021a).

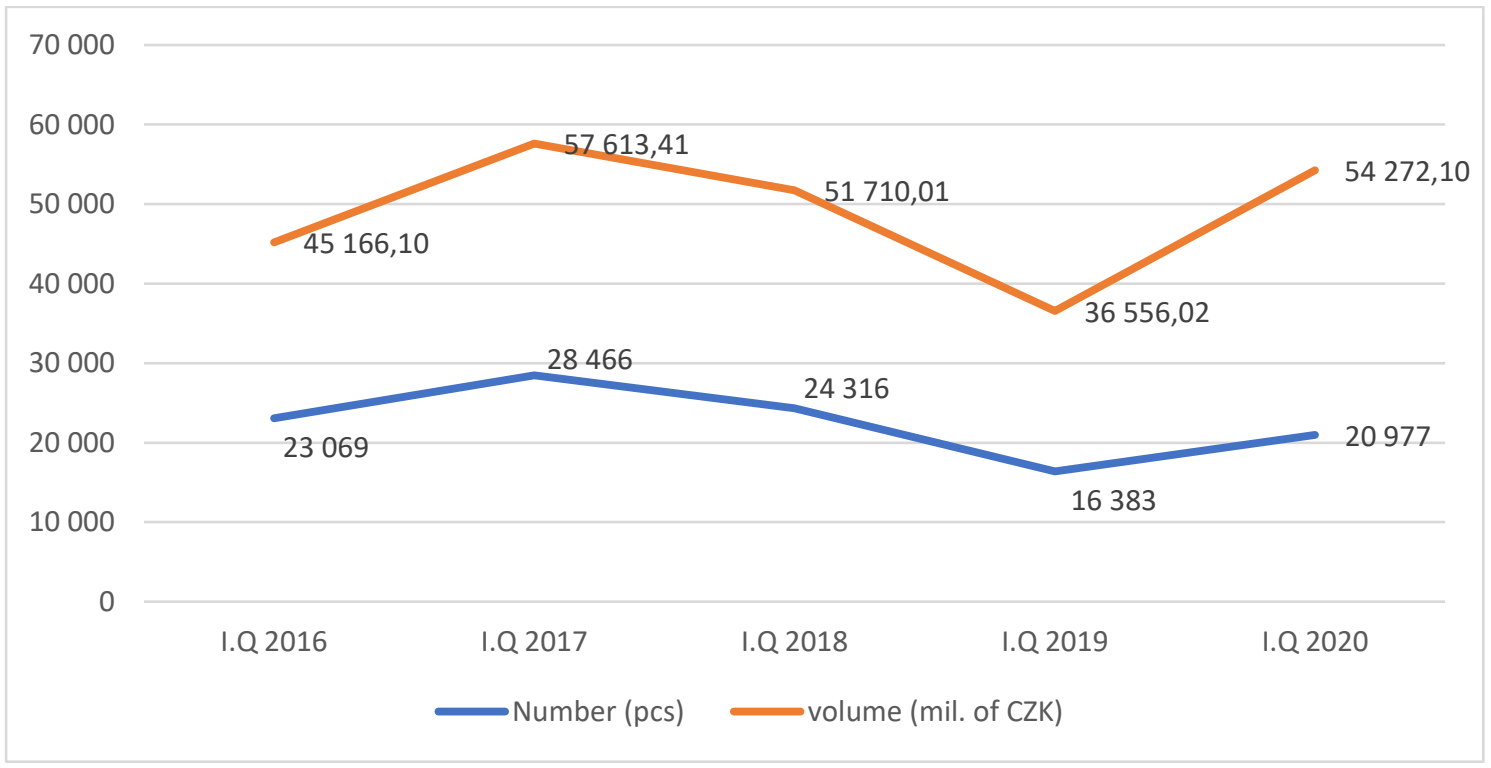


Figure 3. Development of the volume and number of mortgage loans in the first quarter of 2016-2020, source own processing using (Hypoindex.cz, 2021b)

\subsection{Correlation Analysis}

In this article correlation coefficients between interest rate and number of mortgages, respectively volume of mortgages will be calculated. Their significance will be verified using significance test of the correlation coefficient, where the test statistic (Hedvicakova, 2017; Hedvicakova et al., 2020; Hedvičáková \& Pozdílková, 2018)

$$
T=r \sqrt{\frac{n-2}{1-r^{2}}}
$$

If $|T| \geq t_{15-2,0.975}=t_{13,0.975}=2.16$, series have a similar trend.

From the given relation we will calculate correlation coefficient $r$ :

$$
\begin{aligned}
& 2.16 \leq r \sqrt{\frac{15-2}{1-r^{2}}} \\
&(2.16)^{2} \leq \frac{r^{2}}{\sqrt{1-r^{2}}} \sqrt{13} \\
& \frac{r^{2}}{\sqrt{1-r^{2}}} \geq \frac{(2.16)^{2}}{\sqrt{13}} \\
& \frac{r^{2}}{\sqrt{1-r^{2}}} \geq 1.2940 \\
&|r| \geq 0.8391
\end{aligned}
$$

Correlation coefficient for interest rate and number of mortgages is -0.668 , so the equation (2) is not fulfilled and these two times series do not have similar trend.

Correlation coefficient for interest rate and volume of mortgages is -0.8238 , so the equation (2) is not fulfilled and these two times series do not have similar trend, but the difference between the two values is very small here.

The negative sign of the correlation coefficient indicates a decreasing trend of one variable and an in-creasing trend of the other variable, as can also be seen in the following graph.

In this graph, the variables number of mortgages and the total volume of mortgages are described on the main axis on the left, and the variable interest rate is described on the minor axis on the right. This is necessary due to the very different scale of the individual variables.

\section{Conclusions and Discussion}

Although the Czech National Bank cut key interest rates twice in March and lowered the $2 \mathrm{~W}$ repo rate again to $0.25 \%$ in May 2020, the current mortgage market has not changed significantly. Large commercial banks are still waiting, and interest rates have been rising slowly until March 2020. Banks expect a higher risk margin, mainly due to the moratorium 
on loan repayments. Tse (1997) shows that loan loss expectation plays an important role in determining credit rationing. On the other hand, there is a lot of competition in the mortgage market, which significantly affects the interest rate. In particular, newly established banks or "low-cost" banks are trying to gain a foothold in the mortgage market.

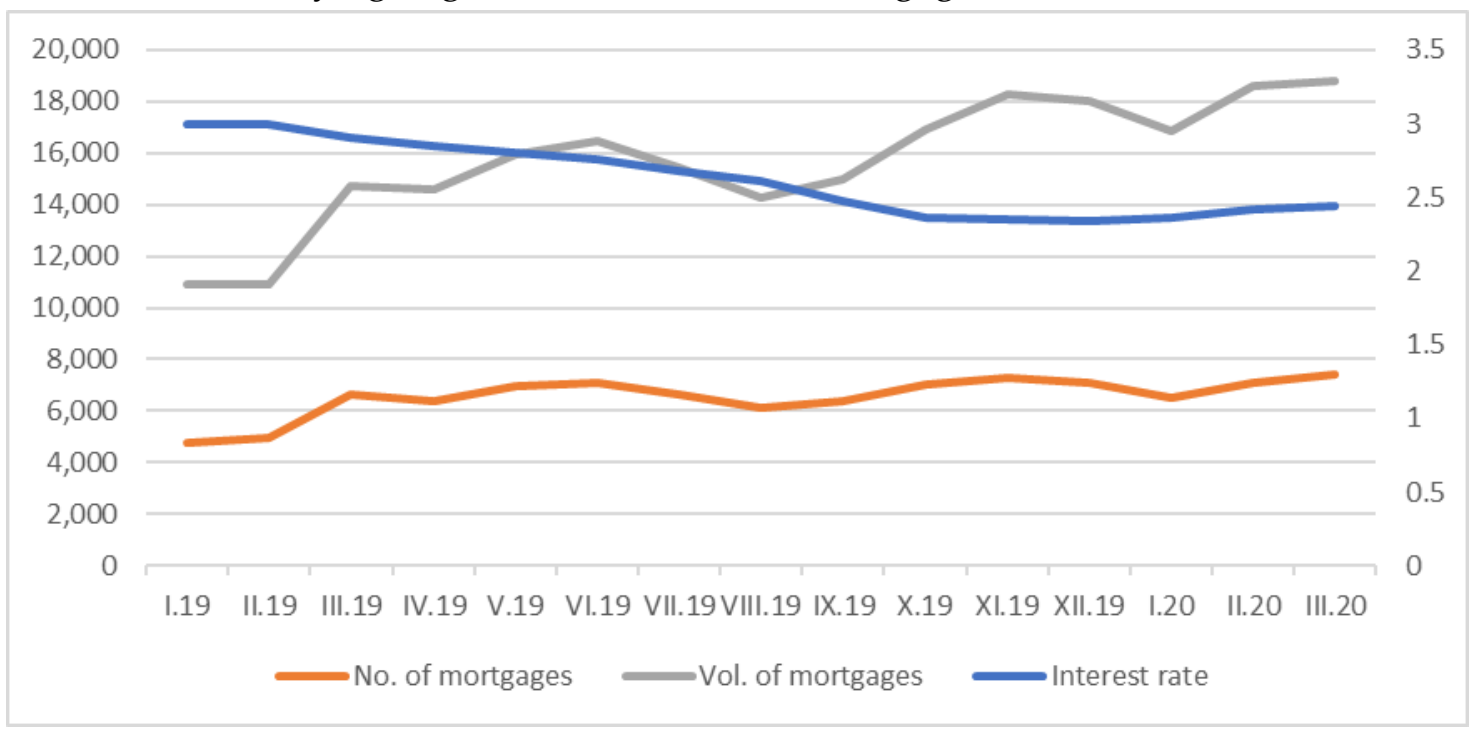

Figure 4. Development of the volume, number of mortgage loans and interest rate, source own processing using (Hypoindex.cz, 2020)

The government bill of April 2020 abolishes the real estate acquisition tax of $4 \%$, with retroactive effect. The tax will no longer be paid by anyone who acquired the property in December 2019 at the latest. The proposal further regulates the extension of the time test for income from the sale of real estate not intended for own living from 5 to 10 years. The extension of the time test will be effective for real estate acquired after 1 January 2021. The aim of the measure is to reduce the space for speculators in the real estate market.

The second change concerns the abolition of the possibility to claim interest deductions from newly concluded housing loan agreements as a non-taxable part of the tax base. Interest deductions will still be available to any buyer who acquires the property in December 2021 at the latest. This means that for properties acquired between December 2019 and December 2021, the buyer will not pay the acquisition tax and will be allowed to claim deductions. interest on a housing loan from the tax base. The aim of the measure is to encourage the real estate market negatively affected by the coronavirus crisis and to support the availability of one's own housing (Žurovec, 2020).

Correlation analysis showed, that trends of interest rate and number of mortgage loans and their volume are not similar. This is illustrated by graph, which shows decreasing trend of interest rate and increasing rate of number and volume of mortgages. Using significance test of correlation coefficient was verified, that even the trends in absolute values are not similar.

The question for discussion is how the real estate market and the mortgage market will develop further. Due to the ongoing pandemic, a state budget deficit of CZK 300 billion is currently planned. If we compare the current situation with 2008, when the last financial and later economic crisis in the Czech Republic began, there has been a fall in real estate prices 
and a subsequent significant rise in real estate prices since 2013, when the economy expanded and GDP grew. In addition, at a time of economic crisis, unemployment is rising and thus the purchasing power of the population is declining. However, external factors are at work here and this situation has not yet been sufficiently analyzed and only time will tell what effects the current pandemic will have on the real estate market and mortgage loans.

Due to the fact that the Czech National Bank cut interest rates twice during March and for the third time in May, many consumers expect that the interest rate on mortgage loans will fall. Some analysts even predict a reduction in the interest rate on mortgages to the values of 2016 and 2017, when interest rates reached their minimum. Given the current situation, where banks are still waiting for government action on coronavirus, it can be predicted that banks in this uncertainty will wait for interest rate cuts and it can be assumed that this risk will be reflected in i.e. Risk margin, which is part of the interest rate. Due to the pandemic, most economists expect the economy to enter a recession. This recession will have a major impact on the banking market. The market is expected to fall in GDP, rise in unemployment and the related loss or inability to pay its liabilities. Some affected consumers may have problems repaying loans, etc. Banks are preparing for this situation and a possible solution is to reduce LTV (effective from 1 April 2020, the central bank increased the LTV limit from 80 to 90 percent, except for investment mortgages), limit DSTI (ratio of total debt and net monthly in-come of the loan applicant) increased from 45 to 50 percent and the limit of DTI indicator (ratio of debt and net income of the loan applicant) was abolished, banks tightened mortgage conditions for foreign income for commuters, stricter Clients working in the sector most affected by the coronavirus crisis (hospitality, tourism, transport), as well as clients who have only employment agreements or agency income, etc., also have conditions. At the same time, the conditions for refinancing mortgage loans are being tightened.

In April 2020, a new law on the credit moratorium from the workshop of the Ministry of Finance will allow bank clients to postpone the repayment of loans and mortgages to any bank and non-bank provider for up to half a year (Ministerstvo financí České republiky, 2020). The postponement of repayments represents a higher administrative burden for banks and the associated higher costs that will have an impact on the economic result.

At the beginning of 2020, an increase in the average interest rate on mortgages was predicted due to risks, and a decrease in the average amount of a mortgage loan was expected, as well as the number of newly concluded mortgages. The amount and number of new mortgage loans is also affected by the real estate market and the development of individual real estate prices. Due to the expected economic recession, it was predicted that real estate sales would most likely stagnate and real estate demand would decline. For this reason, there could also be a decline in interest in new mortgages. However, this interest will also be affected by a possible decline in property prices, which were very high before the pandemic.

As expected, the Czech National Bank (CNB) left rates unchanged at its December meeting. The price of resources on the interbank market has been rising for several months, but banks are currently holding back competition in raising rates. 
Although the average mortgage interest rate fell to $1.96 \%$ in December 2020, according to the Fincentrum Hypoindex (Hypoindex.cz, 2021b), banks' current mortgage rates have almost froze. The last indicator is the Interest rate swap (IRS), for which the value decreased significantly during March. The question for discussion is how interest rates will react to this in the current conditions.

Acknowledgments: The work was supported by the internal project "SPEV - Economic Impacts under the Industry 4.0 / Society 5.0 Concept", 2021, University of Hradec Králové, Faculty of Informatics and Management, Czech Republic. In addition, the authors thank Martin Král for her help with the project.

The paper is also supported by institutional support of University Pardubice.

\section{References}

Česká národní banka. (2021). Měnověpolitické nástroje. https://www.cnb.cz/cs/menova-politika/mp-nastroje/

Chambers, M. S., Garriga, C., \& Schlagenhauf, D. (2009). The loan structure and housing tenure decisions in an equilibrium model of mortgage choice. Review of Economic Dynamics, 12(3), 444-468. https://doi.org/10.1016/j.red.2009.01.003

Draessler, J., Soukal, I., \& Hedvičáková, M. (2011). Cluster analysis of the demand side of the retail core banking services market. EEM Ekonomie a Management, (4), 102-114.

Ferrante, F. (2019). Risky lending, bank leverage and unconventional monetary policy. Journal of Monetary Economics, 101, 100-127. https://doi.org/10.1016/j.jmoneco.2018.07.014

Hedvicakova, M. (2017). Key study of bank accounts for young people with using multi-criteria optimization and fuzzy analysis. Applied Economics, 49(36), 3599-3610. https://doi.org/10.1080/00036846.2016.1265073

Hedvičáková, M., \& Pozdílková, A. (2018). Analytical and Statistical Research of State and Households Health Care Expenditures in the Czech Republic. In Hradec Economic Days, 2018 (Vol. 8, pp. 311-318).

Hedvicakova, M., \& Pozdílková, A. (2018). The Development of Mortgage Loans with Using Regression Analysis. Journal of Engineering and Applied Sciences, 13, 7003-7007. https://doi.org/10.36478/jeasci.2018.7003.7007

Hedvicakova, M., Pozdilkova, A., \& Piwowar, A. (2020). Analysis of the Health Spending and GDP in the Visegrad Group and in the Germany. In P. Maresova, P. Jedlicka, K. Firlej, \& I. Soukal (Eds.), Hradec Economic Days (Vol. 10, pp. 235-243). https://doi.org/10.36689/uhk/hed/2020-01-026

Hypoindex.cz. (2020). Fincentrum Hypoindex březen 2020: Pandemie zatím hypoteční trh neovlivnila. https://www.hypoindex.cz/clanky/fincentrum-hypoindex-brezen-2020-pandemie-srazila-hypotecni-trh-octvrtinu/

Hypoindex.cz. (2021a). Fincentrum Hypoindex - vývoj. https://www.hypoindex.cz/hypoindex-vyvoj/

Hypoindex.cz. (2021b). Fincentrum Hypoindex prosinec 2020: Sazby překvapivě dál klesají, objemy lámou rekordy. https://www.hypoindex.cz/clanky/fincentrum-hypoindex-prosinec-2020-sazby-prekvapive-dal-klesajiobjemy-lamou-rekordy/

Kim, J. (2015). Household's optimal mortgage and unsecured loan default decision. Journal of Macroeconomics, 45, 222-244. https://doi.org/10.1016/j.jmacro.2015.05.002

Kinghan, C., McCarthy, Y., \& O'Toole, C. (2019). How do macroprudential loan-to-value restrictions impact first time home buyers? A quasi-experimental approach. Journal of Banking E Finance, 105678. https://doi.org/10.1016/j.jbankfin.2019.105678

Kokas, S., Vinogradov, D., \& Zachariadis, M. (2020). Which banks smooth and at what price? Journal of Corporate Finance, 65, 101509. https://doi.org/10.1016/j.jcorpfin.2019.101509

Král, M. (2017). Modelling of Savings in Decentralised Cash Processing Costs in the Czech Republic. In Hradec Economic Days 2017 (pp. 478-485).

Ministerstvo financí České republiky. (2020). P̌̌EHLEDNĚ: Odklad splátek úvěrů a hypoték kvůli koronaviru. https://www.mfcr.cz/cs/o-ministerstvu/sluzby-verejnosti/komunikace-s-verejnosti/casto-kladeneotazky/uverove-moratorium-38130

Pozdílková, A., \& Hedvičáková, M. (2017). Regression Analysis of Mortgage Loans on the Czech Banking Market. In Liberec Economic Forum 2017 : Proceedings of the 13th International Conference (pp. 19-27).

Svobodova, L., \& Hedvicakova, M. (2018). Mortgage Loans as a Way of Financing Business Activities. Journal of Engineering and Applied Sciences, 2018(13), 457-462. https://doi.org/10.36478/jeasci.2018.457.462 
Tse, R. Y. C. (1997). Optimal loan size and mortgage rationing. Journal of Property Finance, 8(3), 195-206. https://doi.org/10.1108/09588689710175024

Žurovec, M. (2020). Daň z nabytí nemovitých věcí zrušena se zpětným účinkem k prosinci 2019. Ministerstvo financí České republiky. https://www.mfcr.cz/cs/aktualne/tiskove-zpravy/2020/zruseni-dane-z-nabytinemovitych-veci-se-38157 